911.3

\author{
- Ни ШІ \\ ьвівський н ціон льний університет імені в н \\ вул. . орошенк , 41, м. ьвів, 79000, кр їн
}

озглянуто н укові підходи до формув ння нового світового порядку, розроблені з хідними вченими, що відобр ж ють три моделі глоб льної структури вл ди: однополярну, біполярну і б г тополярну.

лючові слов : новий світовий порядок, глоб льне регулюв ння, глоб льне співробітництво, глоб льне упр вління.

p нсн ціон ліз ція економічної діяльності н прикінці ст., фін нсово-економічн криз н поч тку ст. з свідчили, що високі темпи економічної глоб ліз ції потребують формув ння нового світового порядку, який відповід тиме вз ємоз лежності кр їн і м крорегіонів.

н лізу н укової літер тури виплив є, що ця проблем ще не перебув є в центрі ув ги суспільної геогр фії.

ш мет - розкрити н укові підходи до формув ння нового світового порядку відомих з хідних учених, з'ясув ти геопросторову орг ніз цію центрів військово-стр тегічної т економічної сили в контексті з пропонов них підходів. підст ві н лізу емпіричного м тері лу опис но н ше б чення світового порядку в перехідний період від естф льської моделі політичної вл ди до нової моделі.

роблем формув ння спр ведливого суспільств бере поч ток у д лекому минулому. писи т кого суспільств є у міфології, релігійних ученнях “про кінець світу", соці льних утопіях, футурологічних прогноз х. окрем, н лізуючи ретроспективні погляди н м йбутне, як прикл ди н йд вніших уявлень учені н водять утопію д вньогрецького філософ енон, який висловив припущення про те, що в м йбутньому всі люди ст нуть однією великою общиною, емлю порівнюв в $з$ г льним п совищем, н якому всі вівці п суться під н глядом одного п стух [5, с. 126]. г то мислителів ( . екон, . ор, . мп нел, . нт, . ен- імон, . ур'є, . уен т ін.) висув ли різні утопічні теорії, у яких м йбутне суспільство визн ч ли як суспільство одн кових можливостей для всіх, в б г тьох з них вони з клик ли не тільки до побудови доскон лого суспільств, й до об'єдн ння всіх людей і кр їн у єдине суспільство. онцепція єдиного світового порядку бул в усіх релігіях. прикл д, имськ к толицьк церкв ст л першою спр вді тр нсн ціон льною орг ніз цією.

свідомлення глоб льної кризи у другій половині ст., тр нсн ціон ліз ція економічної діяльності ктивізув ли розробку теорії нового світопорядку, як н бул колективного х р ктеру в т ких інституціях, як соці ція сприяння , имський клуб, іжн родний інститут прикл дних досліджень, нститут світового порядку. $\mathrm{p}$ мк х роекту моделей світового порядку опубліков но низку пр ць, які виклик ли інтерес

(C) ниш ., 2010 
серед учених т гром дськості, оскільки в них розкрив ли м йбутнє у глоб льному контексті. йпослідовніше глоб льне реформув ння опис не в доповідях имського клубу, зокрем , в десятій доповіді “ ороговк з в м йбутне” (1980), втором якої був врилишин.

цій доповіді н широке обговорення винесено модель м йбутнього світового порядку. чений пост вив пит ння про те, чи ре льно нині вести мову про “спільну долю” і “світовий л д” з огляду н глоб льне розмежув ння, численні конфлікти і відносну сл бкість суч сних світових інституцій. ін н вів чинники, які сприяють світовій інтегр ції, т причини, які змушують висув ти проекти м йбутнього світового л ду. еред н йв гоміших сприятливих чинників він н зв в з грозу тот льного знищення, зрост ння усвідомлення цілісності світу, вз ємоз лежності між кр їн ми. еред потенційних г льмівних чинників - врилишин виділив ідеологічні розбіжності, конфлікти і релігію, які можуть хіб що сповільнити його н ближення [4, с. 191-192].

ередб чити в рі нти формув ння світового л ду, перекон ний . врилишин, теоретично можливо, проте ймовірність появи кожного з них не дуже велик . ослідник н зв в т кі дв в рі нти. ерший ч стини людств у світовій війні з з стосув нням ядерної зброї. дн к імовірність т кої події, н його думку, дуже м л , оскільки розв'яз ння т кої війни позб влене сенсу. ругий в рі нт передб ч є створення однією могутньою кр їною світової імперії бо 3 пров дження гегемонії [4, с. 194].

зн чимо, що в доповіді з десять років до р дик льних перетворень у соці льних кр їн х . врилишин не тільки передб чив хід розвитку подій, й визн чив шлях переходу від пл нової до ринкової економіки - повернення до прив тної вл сності.

прикінці 1990-х років у н укових кол х розгорнулися дискусії про глоб льне упр вління т його роль у суч сній світовій політиці. думку вчених, естф льську модель світу, побудов ну н принцип х держ вного суверенітету, поступово повинн 3 мінити нов модель світоустрою, як відповід є суч сним ре ліям розвитку глоб льних процесів. исокі темпи економічної глоб ліз ції потребують узгодженої політичної системи їі регулюв ння н глоб льному рівні. уковці н зив ють різні форми глоб льного регулюв ння, головними серед яких є глоб льне співробітництво, з якого виріш льну роль у проведенні узгодженої світової політики відігр в тимуть суверенні держ ви, і глоб льне упр вління, з якого н дн ціон льні міжн родні орг ніз ції будуть втономні від держ в у процесі ухв лення рішень. они припуск ють, що глоб льне упр вління може скл стися як стихійно, шляхом вз ємодії передусім економічних т фін нсових інститутів, т к і шляхом пл номірного його формув ння н 3 с д х консенсусу всіх глоб льних суб'єктів.

ині у світовій політиці, як з зн ч ють деякі вчені, сформув лось декільк основних концепцій з орг ніз ції глоб льного регулюв ння. і концепції передб ч ють бо створення нових інститутів, що н й декв тніше відповід ють новим глоб льним процес м, бо еволюцію і тр нсформ цію функцій уже н явних міжн родних орг ніз цій.

дним з в рі нтів вирішення політичної глоб ліз ції, як ув ж ють, м є бути з пров дження світової демокр тії у формі світової республіки [10, с. 19]. ов форм гло6 льного упр вління, н думку вчених, повинн м ти т ку орг ніз ційну структуру, як б, з одного боку, з безпечил упр вління глоб льними процес ми, 3 іншого, - не допуск л н дмірної концентр ції т центр ліз ції вл ди. ерший в жливий принцип побудови світової республіки - створення політичних одиниць регіон льного м сшт бу як проміжних л нок між окремими держ в ми і глоб льними структур ми. ругий - 
принцип субсиді рності, згідно з яким світову республіку треб створюв ти знизу вверх, відповідно до пр вил демокр тії, від гром дян і від окремих держ в до регіон льних союзів. он м є бути не центр лістською, федер тивною світовою республікою [10, с. 14].

емокр тичн легітиміз ція світової республіки може відбув тися трьом шлях ми: перший - гром дянськ легітиміз ція як волевиявлення всього н селення світу, другий - держ вн легітиміз ція як волевиявлення всіх держ в світу, третій - комбінов н стр тегія: свою демокр тичну легітиміз цію світов республік м є отрим ти шляхом поєдн ння гром дянської і держ вної легітимності. рг ніз ційн структур світової держ ви буде скл д тися з двох п л т: п л ти гром дян і п л ти держ в [10, с. 20].

дн к, н перекон ння більшості вчених, у н йближчій перспективі не можн сподів тися, що людство піде шляхом створення єдиної моделі уніт рного світопорядку [5, c. 131].

поч тку 1990-х років виникл одн з поширених п р дигм світової політики концепція “кінця історії”, втором якої був мерик нський політолог ренсіс укуям . оловн ідея концепції - нов геополітичн структур світу буде грунтув тися н політичному й економічному лібер лізмі. “ певно ми ст немо свідк ми - стверджув в укуям - кінця історії як т кої, тобто кінцевої точки ідеологічної еволюції людств й універс ліз ції з хідної лібер льної демокр тії як ост точної форми людського пр вління" [9, с. 136]. чений вв ж є, що вн слідок пор зки дянського оюзу в “холодній війні” у лібер льної демокр тії “нем є льтерн тиви”, тому ідеологічн еволюція 3 вершен і можн говорити про універс льність з хідної лібер льної демокр тії.

міст поняття “кінець історії” в вторському контексті м є як ідеологічне, т к і політичне з б рвлення. . укуям розгляд є “з хідну лібер льну демокр тію” т “економічний і політичний лібер лізм” як межу можливого вдоскон лення людств . “ iнець історії” озн ч є, що к піт лістичн систем - це н йдоскон ліш форм суспільного устрою, і тому вон повинн існув ти вічно. рім того, з міркув нь ученого видно, що ет лоном т кого доскон лого суспільств є . ому, стверджуючи, що “кінець історіі” озн ч є “універс ліз цію”, втор н м г ється випр вд ти мерик ніз цію світу. вітов політик, н думку політолог , знову буде політикою з г льного миру. хід знову користув тиметься бл г ми, отрим ними від миру і процвіт ння, його інститути, імовірно, поширяться в глоб льному м сшт бі. езумовно, деякі конфлікти, відбув тимуться у кр їн х третього світу, проте глоб льний конфлікт дійшов з вершення, і не лише в вропі. ому, перекон ний втор, м йбутне буде присвячене не великим 3 хопливим битв м з ідеї, вирішенню буденних економічних і технічних проблем; $і$ все буде відбув тися доволі нудно. кінці ст тті . укуям зізн ється, що його охоплює ност льгія з тим ч сом, коли існув л історія, і він сподів ється, що перспектив скуки допоможе історії розпоч тися знову [9, с. 148].

онцепція “зіткнення цивіліз цій” розроблен директором інституту стр тегічних досліджень . нтінгтоном ( ). книзі “ ротистояння цивіліз цій т змін світового порядку” (1996) втор висунув тезу, згідно з якою, н зміну конфлікту н цій, х р ктерному для XIX ст., н зміну боротьбі ідеологій, що п нув ли в XX ст., прийде “зіткнення цивіліз цій”. думку вченого, у світі після “холодної війни” ідеологічні, політичні чи економічні відмінності втр тили першочерговість, їхнє місце 3 йняли культурні відмінності, глоб льн політик вперше в історії ст л $б$ г тополюсною т мультицивіліз ційною. 
оловн ідея концепції поляг є в тому, що м йбутні світові конфлікти - це конфлікти між цивіліз ціями. цьому новому світі, н думку втор , лок льною політикою ст є етнічн політик, глоб льною - політик цивіліз цій. місце суперництв н ддерж в виходить протистояння цивіліз цій [7, с. 12]. ке протистояння є з грозою міжн родної ст більності.

. нтінгтон стверджув в, що із з кінченням “холодної війни” цивіліз ції, як суб' Єкти світової політики, приходять н зміну н ціям-держ в м. ивіліз ції визн чені ним як “культурні спільноти”, які відрізняються одн від одної мовою, тр диціями, ле н йбільше релігією [7, с. 20]. чений виокремив вісім основних цивіліз цій - 3 хідну, конфуці нську, японську, ісл мську, індуїстську, пр восл вну, л тино мерик нську і, можливо, фрик нську. - нтінгтон стверджув в, що відмінності між цивіліз ціями є головними, оскільки вони формув лися століттями, швидко не зникнуть і є більш консерв тивними. 3 ємовідносини цивіліз цій є потенційно конфліктними, оскільки в основі їхніх відмінностей - цінності й перекон ння, які примирити скл дніше, ніж політичні й економічні інтереси.

думку - нтінгтон , роль нез хідних цивіліз цій зі зрост нням їхньої с мобутності н був тиме щор з більшого зн чення. піввідношення сил між цивіліз ціями зміщується. хідн цивіліз ція, стверджув в . нтінгтон, втр ч є свою колишню могутність, інші цивіліз ції н рощують сили. ез хідні суспільств розвив ють свій економічний потенці л і створюють основу для збільшення військової могутності т політичного впливу. осилення економічного регіон лізму в хідній зії, н лизькому ході т тинській мериці призведе до зміщення співвідношення сил між цивіліз ціями.

оловним елементом нової системи міжн родних відносин, ув ж $є$ втор, ст не в3 ємодія різних цивіліз цій, які групуються н вколо “центр льної кр їни”. ижив ння

ходу, н думку вченого, з лежить від ступеня усвідомлення своєї цивіліз ційної сутності і від його розуміння унік льного ( не універс льного) х р ктеру своєї цивіліз ції. никнути міжцивіліз ційних конфліктів можн буде тільки в р зі готовності лідерів різних цивіліз цій підтрим ти поліцивіліз ційний х р ктер світової політики. нтінгтоном, н йбільше протистояння відбув тиметься між ходом т рештою цивіліз цій. еред інших в жливих протистоянь втор н зив в: хід - ісл мськ цивіліз ція; з хідне християнство - пр восл вне християнство.

н ш погляд, існув ння різних культур і цивіліз цій не створює протистояння і конфліктів. “ іткнення цивіліз цій” можуть виник ти тоді, коли одн 3 них н м г тиметься ст ти н д іншою і н в'яз ти свої цінності іншим цивіліз ціям. ку політику демонструють , які під виглядом боротьби з тероризмом і з пров дження демокp тії н пр ктиці здійснюють геополітичний переділ світу н свою користь.

ст тті “ динок супердерж в ”, опубліков ній 1999 р., . нтінгтон про н лізув в нинішню глоб льну систему вл ди і д в прогноз геополітичної ситу ції н м йбутнє. чений з зн чив, що суч сн глоб льн структур вл ди є “гібридом”, деякою одноб г тополярною системою, у якій існує одн супердерж в і декільк великих держ в [6, с. 36]. ині глоб льн структур вл ди м є декільк рівнів. верхньому рівні перебув є - єдин н ддерж в , як перев ж є у всіх сфер х вл ди. другому рівні - “головні регіон льні держ ви”: імеччин , р нція у вропі; осія в вр зії; ит й і понія в хідній зії; ндія н івдні зії; р н н південному з ході зії; р зилія в тинській мериці, т кож i ігерія в фриці. третьомурівніє “вторинні регіон льні держ ви”, інтереси яких ч сто супереч ть інтерес м могутніших регіон льних держ в. о цієї групи н леж ть елик рит нія (щодо імеччини і 
p нції), кр їн (щодо осіі), понія (щодо ит ю), еспублік орея (щодо понії), кист н (щодо ндії), удівськ р вія (щодо р ну) i ргентин (щодо р зилії).

инішня систем вл ди, стверджує втор, не вл штовує , оскільки вони воліли 6 м ти однополярну систему. еликі держ ви н д ють перев гу 6 г тополярній системі, бо вони розцінюють пр гнення до гегемонії як з грозу своїм інтерес м. проби створити однополярну систему тільки стимулюють пр гнення великих держ в до побудови б г тополярної системи [6, с. 37]. . нтінгтон ув ж є, що глоб льн систем вл ди упродовж двох н йближчих десятиліть перебув тиме в ст ні одно-б г тополярності, перш ніж вон ст не б г тополярною. Змушені будуть існув ти в умов х 6 г тополярності.

думку - нтінгтон , вз ємодія чинників сили і культурних чинників вплив тиме н формув ння союзів і нт гонізмів між держ в ми. погляду культурних чинників співробітництво н йімовірніше, перекон ний втор, між кр їн ми, які м ють спільну культуру, нт гонізми - між кр їн ми різних культур. погляду чинників сили, і вторинні регіон льні держ ви м ють спільні інтереси в пл ні обмеження п нув ння головних держ в регіону.

я вз ємодія чинників сили і культури д є змогу, з слов ми . нтінгтон , припустити, що , імовірно, м тимуть скл дні відносини з основними регіон льними держ в ми, хоч 3 і р зилією вони будуть менш скл дними, ніж з іншими. іншого боку, відносини з усім вторинними регіон льними держ в ми будуть відносин ми співробітництв . одноч с відносини з держ в ми, які м ють подібні культури, будуть тіснішими, ніж з держ в ми, які н леж ть до різних культур. відносини між основними і вторинними регіон льними держ в ми, які н леж ть до однієї цивіліз ції, будуть менш нт гоністичними, ніж відносини між кр їн ми різних цивіліз цій [6, c. 47].

ідомий мерик нський політолог . жезінський у книзі “ елик ш хівниця. нув ння мерики і його геостр тегічні імпер тиви” з пропонув в концепцію нового світового порядку, головн ідея якої - мерик нськ гегемонія нового типу. оловн ув г присвячен геостр тегії у вр зії. еополітичний простір вр зії втор зобр зив у вигляді ш хівниці, де поведінк фігур визн чен їхніми геостр тегічними т геоекономічними потенці л ми.

думку . жезінського, “перев г н д вр зійським простором слугує центр льною основою для глоб льного членств " [2, с. 53], з цік влені зміцнюв ти і зберіг ти геополітичний плюр лізм у вр зії. гідно з його стр тегією, дом г ються т кої геополітичної структури в вр зії, щоб т м не було однієї великої держ ви, б г то середніх, порівняно ст більних і помірно сильних, проте обов'язково сл бших, ніж . е можн здійснити, перекон ний втор, якщо вд сться попередити створення ворожих ко ліцій у вр зії, зд тних кинути виклик домінуючій ролі [2, с. 234].

книзі “ ибір: світове п нув ння чи світове лідерство” (2004) . жезінський продовжив обгрунтовув ти роль у формув нні нового світового порядку. ін з зн ч є, що унік льне ст новище у світовій ієр рхії сьогодні з г льновизн чене. “ уч сному світові може не подоб тись провідне ст новище : світ може не довіряти мериці, може обурюв тись, ч сом н віть змовлятися проти неї. роте у пр ктичній площині світ не може прямо виступити проти неї”. оожному р зі, з зн ч чив д лі втор, з кінчення мерик нської гегемонії, яке врешті-решт н ст не, не приведе до відновлення б г тополярності між великими держ в ми, які п нув ли н міжн родній рені впродовж ост нніх двох століть, не спричинить появи іншого гегемон , який з - 
мість перебере н себе схожу військову, н уково-технічну і соці льно-культурну перев гу в усьому світі. еликі держ ви минулого століття, перекон ний він, н дто сл бкі, щоб перебр ти н себе ту роль, яку сьогодні відігр ють [3, с. 16].

. жезінський ув ж є, що зовсім м лоймовірно, що у н йближчі дв десятиліття н буде політичної єдності, дост тньої для суперництв зі н військово-політичній рені. осія, н його думку, більше не є імперською держ вою і головне 3 вд ння для неї - соці льно-економічне відродження; поширен у 1980-ті роки думк , що понія неминуче ст не н ступною "н ддерж вою”, сьогодні звучить іронічно. втор вв ж є т кож, що ит й, н віть якщо зберіг тиме високі пок зники економічного зрост ння, буде в ліпшому р зі регіон льною держ вою. ндія т кож не може претендув ти н роль глоб льного лідер [3, с. 17].

о ліція зг д них вище держ в, перекон ний . жезінський, є м лоймовірною через їхні історичні конфлікти й територі льні претензії. дн к н віть якщо вони вИникнуть, їм бр кув тиме єдності й сили, як для того, щоб скинути $з$ ії̈ місця, т к і для підтрим ння ст більності в світі. йголовніше те, що з г льне невдоволення мерик нською гегемонією не може подол ти суперечностей між інтерес ми різних держ в. ому вчений вв ж є, що конфронт ції, які виник тимуть у р зі з неп ду, зд тні призвести до регіон льного н сильств, що ст є небезпечним з умов поширення озброєнь м сового знищення [3, с. 18].

прикінці втор з зн чив, що перед стоїть вибір: вон може здійснюв ти світове п нув ння, н в'язуючи світу силовими метод ми свої пр вил гри бо вон може ст ти світовим лідером, який виступ є г р нтом міжн родної безпеки. першому вип дку є “н ддерж вою-мінус", в другому - “н ддерж вою-плюс" [3, с. 183].

йбільше прихильників здобул концепція побудови нового світового порядку шляхом тр нсформ ції - дея реформув ння з'явил ся ще в 70-ті роки XX ст., одн к тільки після з кінчення “холодної війни” відкрилися нові можливості для її реліз ції. думку вчених, перев ги міжн родного співробітництв т інтегр ції в умов х глоб ліз ції потребують перед чі ч стини суверенних пр в держ в н дн ціон льним орг ніз ціям.

доповіді “ овістки дня для світу” (1992) з пропонов но низку ідей щодо реформув ння цієї орг ніз ції, які можн розгляд ти як прогр му ст новлення нового світового порядку, ре ліз ція яких перетворил б тї у головного суб'єкт упр вління світовими процес ми. оповідь передб чил розширення повнов жень енер льного секрет ря, підвищення ролі ди езпеки, включ ючи розширення її скл ду й обмеження пр в вето, створення глоб льної системи спостереження з н дзвич йними ситу ціями, под льше розгорт ння миротворчих сил , зміцнення фін нсової 6 зи орг ніз ції.

ропозиції з 1994 р. модифіков ні й дет лізов ні у доповіді

(1999), як елементи “нової глоб льної рхітектури” з пропонов ні т кі інститути: вітовий 6 нк, вітов екологічн уст нов, вітовий інвестиційний фонд, іжн родний кримін льний суд, воп л тн енер льн с мблея ,

есії исячоліття енер льної с мблеї (2000) н голошено, що центром формув ння рхітектури нового глоб льного світопорядку може і повинн бути он глоб льн й універс льн 3 скл дом, 3 співпр цюють усі н йзн чніші неурядові орг ніз ції. рім того, утворює ядро з семи спеці лізов них орг ніз цій, які охоплюють в жливі сфери життєдіяльності людств . 
е ліз ція т кої концепції, н думку вчених, д в л б підст ву говорити про глоб льне упр вління як ф кт, високий ступінь н дн ціон льності, вл стивий цій системі суспільних інститутів, робили 6 їі функціон льно нез лежною від держ в.

онцепція формув ння нового світового порядку - регіон льні інтегр ційні об'єдн ння, які розгляд ють як проміжну л нку між н ціями-кр їн ми і глоб льним співтов риством. кі м крорегіони є н дн ціон льними політичними об'єдн ннями зі своєю в лютою, пр вовими інститут ми т системою безпеки.

ині регіон лізм перетворився в чітко вир жену з г льносвітову тенденцію. контексті т кої тенденції регіони почин ють відігр в ти щор з в жливішу роль у глоб льних процес х. окрем , регіон льні держ ви, створюючи т кі об'єдн ння, можуть посилити свої позиції н міжн родній рені. е с ме стосується м лих і сл бких кр їн у скл ді т ких об'єдн нь. кономічний регіон лізм у вропі - , мериці , івденно- хідній зії - . ільшість експертів і вчених перекон н , що шляхом переговорів і укл дення угод між регіон льними льянс ми можн створити глоб льне співтов риство.

дн к опоненти т кого в рі нт їм 3 перечують, вв ж ючи, що не готові будуть піти н віть н незн чні обмеження вл сної с мостійності в обмін н перев ги т ких союзів. це не озн ч є, що т кі об’єдн ння не потрібно створюв ти.

еякі вчені прогнозують формув ння двоблокової структури світового порядку між розвиненими кр їн ми івночі і кр їн ми, що розвив ються, івдня. они стверджують, що протистояння б г тих і бідних кр їн, можливо, перевищув тиме протистояння ч сів деколоніз ції. прикл д, . еннеді у книзі “ ступ ючи у ХХІ століття” розглянув проблему відносин між кр їн ми івночі і івдня як головний виклик світу в н йближчому м йбутньому. ндійські вчені пишуть про можливість “нової холодної війни" між кр їн ми івночі і кр їн ми івдня. відув ч прогр ми допомоги кр їн м, що розвив ються, . пет попередж є: "ризик зриву великим глоб льним ндеркл сом світової ст більності дуже ре льний”. . . уфм н 3 ди н ціон льної безпеки не виключ є, що “може відбутися війн між кр їн ми івночі і івдня, ініційов н економічною нерівністю” [8, с. 112]. думку лерст йн , бідні кр їни не змиряться з постул том нерівності, результ том якого може бути глоб льний економічний кол пс.

мерик нський учений · перо (1989) перекон ний, що між кр їн ми івночі й

івдня основною проблемою є створення вз ємовигідної системи відносин для всіх уч сників. ін з зн чив, що у відносин х між кр їн ми цих двох блоків не існує добре розробленої системи з г льного доступу як до форм льних, т к і до неформ льних в желів упр вління. сфері політики головні політико-економічні інститути ( вітовий б нк, ) створені кр їн ми івночі, і тому відобр ж ють їхню п нівну роль. огляду н це кр їни івдня м ють обмежену систему в желів і з собів, щоби вплив ти н кр їни івночі, які сл бко ре гують н всі вимоги з боку кр їн івдня.

івності між кр їн ми івночі і івдня не буде, перекон ні деякі вчені, оскільки перші н б г то могутніші, другі - дуже роз'єдн ні й бідні, гірше озброєні, економічно сл бкі, політично не солід рні [8, с. 113]. ой ф кт, що для кр їн, які розвив ються, суттєвішими є зв'язки по лінії івніч- івдень, нег тивно вплив $€$ н їхню зд тність вирішув ти в жливі для них проблеми вл сними сил ми [5, с. 266].

еякі спеці лісти висловлюють думку про те, що против гою кр їн м івночі може бути ух еприєдн ння. дн к інші з зн ч ють, що “філософія солід рності”, як грунтується н визн нні вз ємної з цік вленості й вз ємоз лежності, не ст л н стільки 
в жливою, щоб д ти змогу цій орг ніз ції вирішув ти в жливі соці льно-економічні проблеми кр їн, що розвив ються, і з безпечити 6 л нс інтересів івніч- івдень [1, c. 15].

тже, з умов перехідного періоду новий світовий порядок поєднує в собі елементи одно-, дво- і $б$ г тополярності. е можн пояснити т к:

1) якщо держ ви світу р нжув ти з ступенем впливун зовнішній рені, то можн говорити про однополярний світ, оскільки нині з цим пок зником ніхто не перевищує . р вд, вплив цей не бсолютний. ро це свідч ть, зокрем, війн в р ку, до якої призвело геофін нсове суперництво між $\mathrm{i}$. кономічн і фін нсов гегемонія грунтується н п нув нні дол р у світових розр хунк х з енергоресурси, золото, зерно. 2000 р. р к у здійсненні міжн родних опер цій 3 н фтою перейшов н євро, пізніше перевів у цю в люту всі свої фонди в ;

2) світовий порядок можн розгляд ти як біполярну модель, якщо бр ти до ув ги проблему безпеки вижив ння, тобто військово-стр тегічний потенці л. ким потенцілом нині володіють і осія, якщо не бр ти до ув ги кількісні т якісні диспропорції;

3) якщо бр ти до ув ги економічний потенці л, незв ж ючи н домінув ння , , можн говорити про б г тополярний світ.

н ведених вище концепціях відомі вчені н м г ються д ти відповідь н пит ння: куди рух ється світ після з кінчення “холодної війни” - до монополярного пр вління однією супердерж вою чи до нової біполярності івніч- івдень, може, глоб льн модель вл ди буде б г тополярною? оки що можн ск з ти одне: ми є свідк ми еволюції від міждерж вного до нового світопорядку, який з умов перехідного періоду поєднує в собі елементи одно-, дво- і 6 г тополярності.

1. 2 ев ., рылов . вижение еприсоединея не к нуло в лету // еждун р. жизнь. 1996. № 4. .9-15.

2. жезінський . елик я ш хм тн я доск . осподство мерики и его геостр тигические импер тивы. ., 1998.

3. жезінський . ибір: світове п нув ння чи світове лідерство / ер. 3 нгл. $\therefore$ ид-во “ иєвоогилянськ к демія", 2006.

4. врилищин . о ефективних суспільств: ороговк зи в м йбутне: доп. имському лубові / упорядн. . убцов: 3-те вид., доп. .: , 2009. 248 с.

5. джиев . еополитичекие горизонты оссии: контуры нового мирового порядк / . . джиев. $\therefore$ кономик , 2007.751 с.

6. нтингтон . динок я супердерж в // кту льные проблемы вропы: б. обзоров и рефер тов. . ентр н учн. ислед. глоб. и регион. проблем. ., 2003. . .9-37.

7. нтингтон . ротистояння цивіліз цій т змін світового порядку / ер. 3 нгл. ьвів: льв рія, $2006.473 \mathrm{c}$.

8. ткин . . ировой порядок XXI век . . . $\quad$, 2002.512 c.

9. укуям . онец истории? // опр. философии. 1990. №3. . 136-148.

10. еффе . семирн я федер тивн я республик // кту льные проблемы вропы: б. обзоров

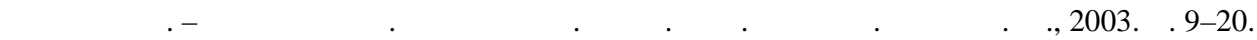




\title{
SCIENTIFIC APPROACHES TO NEW WORLD ORDER FORMATION
}

\author{
. Knysh \\ Ivan Franko National University of Lviv, \\ . Doroshenko St., 41, UA - 79000 Lviv, Ukraine
}

Scientific conceptions to new world order formation developed by Western scientists are examined. These conceptions reflect three models of global structure of power: monopolar, bipolar and multipolar.

Key words: new world order, global regulation, global co-operation, global governing.

\section{- ныш}

ьвовский н цион льный университет имени в н р нко,

ул. . орошенко, 41, г. ьвов, 79000, кр ин

ссмотрено н учные подходы к формиров нию нового мирового порядк , $\mathrm{p}$ зр бот нные 3 п дными учеными, которые отр ж ют три модели глоб льной структуры вл сти: однополярную, биполярную и многополярную.

лючевые слов : новый мировой порядок, глоб льное регулиров ние, глоб льное сотрудничество, глоб льное упр вление.

т ття н дійшл до редколегії 09.09.2009 рийнят до друку 20.09.2009 